\title{
Political Parties of Lithuania: Canonization of the Fight for Power, Deconstruction of Responsibility and the Actualization of Internal Security
}

\begin{abstract}
This article analyzes aspects of the activity of political parties as well as the lack of internal security harmony in Lithuania. The activity of Lithuanian parties is researched pursuant to the standpoint that the desire of the parties for power is greater than their readiness to organize effective political governing. With the fight for power having become an aim in itself, the parties do not pay the required attention to the prediction of the results of their political governing, promise extensive and rapid changes and begin unprepared reforms. Inadequate ambitions of political power are typical of irresponsible parties. Society fails to understand the responsibility standards of the parties, whereas broken promises of the parties are associated with lies. The article emphasizes that internal security is impossible without effective political governing. Unexpected results of the policy(s) conducted by the parties in power threaten internal security and their consequences build up social tensions. Simultaneously, the discontent of society with the present democracy grows. The de-legitimation of the political regime, dominated by the parties and party elites, does not grant internal credibility to the democratization of Lithuania. Lithuania remains a weak and internally insecure democracy.
\end{abstract}

\section{Introduction}

Political parties are criticized in all countries, yet democracies have thus far not learned to exist without parties. Though parties, due to media, social movements and the impact of experts, have lost the role of independent political agents, they remain influential political players. Research on Lithuanian parties has reached such a stage that it is stated that the economic backwardness, social polarization, political alienation, discontent with the present democracy, internal security associated with the weakness or incapability of the parties are getting systemic. Within the incapability structure of the parties, their hypertrophic ambitions for political power are disproportionate to their ability to govern and the

\footnotetext{
* Prof. dr. Vaidutis Laurenas is Rector of Klaipeda University. Address for correspondence: Kretingos 51-55, LT-92294 Klaipeda, Lithuania, tel. +370 46 398920, e-mail: vaidutis.laurenas@ku.lt
} 
lack of political responsibility should be pointed out.

The first premise of this research is: a complex indicator of the incapability of the parties is the ineffectiveness of the political governing. In Lithuania, parties have created a weak or ineffective democracy. Regular and competitive elections are held, the opposition is operating, yet democratic governing is ineffective. Democratic governing is considered to be ineffective or weak when the democratic regime, following its nature, opens perspectives for the expression of diverse interests and public conflicts, but is incapable of coordinating those interests and resolving conflicts. A weak democracy is dangerous to internal security. Internal security is supported by relations of social stability, when certain individuals do not pose a threat to the welfare of other individuals as well as to the common order, do not expect such a threat from others, trust each other and are ready to cooperate in solving public problems for the good of common goals. A conflict of interests is characteristic of any society, but internal security is not lost if interests coordination intermediaries, which usually are parties, are dependable. However, when a conflict of interests reaches the level when particular groups begin to thrive at the expense of others and the latter even emigrate, i.e. migrate from the state and society, internal security faces real threats. The population of Lithuania, one of the poorest European countries, refrains from identifying itself with political democracy. Damaging, economically not provided democracy is not stable and irreversible. With the economic inequality developing into social differentiation, incompatible with human dignity, citizens neither feel nor are politically equal. In Lithuania, more than half of the population is dissatisfied with the present democracy, expectations of having a strong leader are as great here as anywhere, conviction that human rights are not respected prevails, extreme distrust of political parties and those in power is present, and it is believed that the State serves not for the welfare of all its citizens, but for particular narrow interests groups. ${ }^{1}$ All these are indications of internal insecurity. Society has split in a social economic sense'; it has become more conflict-bound when human value came to be measured by a human's market value. ${ }^{3}$ Since the trust in government institutions and parties is

\footnotetext{
${ }^{1}$ Matulionis A., sud, Europa ir mes, Vilnius: Gervele, 2001; Degutis M. "Lietuvos politinè kultūra visuomenès kaitos sąlygomis" in Jankauskas A., ed., Politiné kultūra ir visuomenés kaita., Kaunas: Naujasis lankas, 2002; Žiliukaite R., Ramonaite A., Nevinskaite L., Beresnevičiūtè V., Vinogradnaite I. 2006, Neatrasta galia. Lietuvos pilietinés visuomenés žemélapis. Vilnius: Versus aureus, 2006; Lietuvos tauta: büklè ir raidos perspektyvos. Sud. M. Adomènas, A. Augustinaitis, T. Janeliūnas, D. Kuolys, E. Motieka. Vilnius: Versus aureus, 2007.

${ }^{2}$ Lietuva stojant $i$ Europos Sajunga. Ekonomine, sociologine ir demografine padeties analize. Editorial board: R. Lazutka, A. V. Matulionis, V. Stankūnienè. Vilnius: Institute of Social Research, 2004.

${ }^{3}$ Bernotas D., Guogis A. Globalizacija, socialine apsauga ir Baltijos šalys. Vilnius: MRU Publishing House, 2006.
} 
critical, there is no direct political interaction - conflicts are not solved by the very social groups either. Unresolved conflicts are dangerous because of the unpredictability of their development. It is only known that intolerance and aggression are the consequence of the discontent with living conditions, the reasons for which are generally sought in the activity of other social groups, most frequently no matter which. There are indications that the discontent with living conditions is consolidating the ever growing part of Lithuania's population.

Democratic political governing is not possible without parties and their competition for power, yet competent parties organize the "division" of power in such a way that the process does not escalate conflicts in society and strengthens internal security. Realizing that weak parties are the outcome of a weak civil society, we associate the reasons for a weak democracy in Lithuania with parties. A strong civil society, tolerating and not hindering the state yet counterbalancing its dominance, could not develop right away because of the consequences of sovietization. Meanwhile, parties at the time of their establishment, did not become forms of civil society mouthpieces and, in a sense, overshadowed civil society, but, lacking internal democracy and essentially being closed, separated from civil society. The self-organization of the latter is thriving beyond party borders. The development of civil society in Lithuania, like in other countries of similar development, is determined by the fact that the level of the economic development is not high enough for its members to have sufficient time and means to participate in public activity, but it is neither so low as to preclude them from taking up busy public activity without paying attention to their personal interests. In a passive society, democracy dominated by parties is possible, provided the parties are well aware of their exceptional responsibility for the competences of their members, entrusted with the mandate to govern, as well as the executed policy and do not aggravate the differentiation in society by engaging in fighting for power "without rules". The limitation of the readiness of parties to govern is confirmed by unsuccessful reforms.

The second premise of the research: neither of the two main definitions of post-democracy is directly applicable to Lithuania. The analytical dimension of postdemocracy is resorted to not for the sake of discerning reasons for non-participation in politics, but in order to find out perspectives of the "non-participating democracy". Non-participation in politics is not an exceptional feature of Lithuanian political life, but Lithuania should be attributed to a group of countries where non-participation might mean de-democratization. Thus the analysis of the internal factors of the reliability of Lithuania's democratization or of the irreversibility of 
democracy would be continued. ${ }^{4}$

The diversity of reasons for de-democratization is great; therefore, it is sensible to refer to Ch. Tilly's generalization: there are no mandatory de-democratization conditions, there are only mandatory de-democratization processes. Ch. Tilly points out three such processes: isolation of trust (social capital) networks from public politics; integration of economic, social and other crucial inequality into politics; and the increase in the impact of autonomous power centers on the state and decrease in the citizens' role in politics. ${ }^{5}$ De-democratization is a decreasing accord between those in power and citizens on the issues of state development.

Going back to the conception of post-democracy we would like to note that in analytical constructions it is defined as a situation when, with a low-level participation of citizens, it is expected that those in power will follow democratic governing principles as consistently as when they are controlled by participating society that the relation between citizens and governing institutions will be retained. ${ }^{6}$ At the same time, it is not expected that minorities will stop dictating terms "from the top to the bottom", but it is hoped that the political process will remain open to a discreet and irregular involvement of citizens for the majority of which politics is only a peripheral activity. Post-democracies are analytically construed as political regimes within which the majority of the population would not even feel the absence of democracy. Such a "without-us" state does not mean lethargy, but should rather be called the harmony between parties' activity and internal security. It is simply believed that democracy, as a governing system, has reached the limits of its possibilities. ${ }^{7}$ There also exists a pessimistic scenario of post-democracy, according to which political equality has been lost and it will be necessary to start everything from scratch. ${ }^{8}$ Both conceptions of post-democracy feature the concept of non-democracy. Non-democracy is the incapability to consistently follow the principles of democracy, at the same time refusing to acknowledge the principles of autocracy. A. Ramonaite observes: the population of Lithuania is not against democracy, which, by the way, they link to the freedom of word, responsible and

\footnotetext{
${ }^{4}$ Laurenas V. Normalios politikos genezés atvejis. Klaipèda: Klaipeda University Publishing House, 2001.

${ }^{5}$ Tilly Ch. Democracy. Cambridge: Cambridge University Press, 2007.

${ }^{6}$ Crouch C. Post-Democracy. Cambridge: Cambridge University Press, 2004; Rosanvallon P. Democracy Post and Future. New York: Columbia Universitety Press, 2006; Šerpetis K. Simuliacija kaip aukščiausia postdemokratijos stadija. Inter-studia humanitatis, 2009, No. 9, p. 24-46.

${ }^{7}$ This statement should not be understood in the literary sense. M. Castels points out that a majority of people do not see any alternative to democracy as a form of governing, yet a growing number of citizens begins to think that democracy does not help them cope with everyday life hardships ( (Castels M. Informacijos amžius. Ekonomika, visuomené ir kultūra. Volume 2. Tapatumo galia. Kaunas: Poligrafija ir informatika, 2006, p. 391).

${ }^{8}$ Guéhenno J.-M. Das Ende der Demokratie. München: Artemis und Winkler, 1994.
} 
fair state power, equality referring to laws and respect for human rights but not to elections and parties; however, they believe that Lithuania needs "a strong leader" who is restricted neither by the parliament nor elections. ${ }^{9}$

In the context of post-democracy, political competence should be attentively explored. Political competences are an Achilles' heel of politics. Research on Lithuanian parties abound in recommendations to change methods of parties' activity, to determine the ideological identity and so on; but the issue of their political competences is not, in essence, formulated. Political competence is the capability to define political problems, interpret them as solely political and present their solutions following political principles. To be competent in politics means to have one's own opinion about political processes, even change the direction of these processes. Political competences are specific because they manifest themselves under public acknowledgement. In democracies, the issue of political competences is revealed first, when the authorization of the mandate to govern is under way; second, when those in power employ the given mandate in solving public problems.

The third premise of the research: democratic pluralism is not identical to democratic primitivism. It is important to see the boundary of democratic pluralism which is defined by G. Sartori as the distinction between the "horizontal democracy" and "vertical democracy". ${ }^{10}$ Ignoring this distinction, we would find ourselves in the area of democratic primitivism and "would forget" that political democracy is only a system of political governing, whereas parties are intermediaries between society and those in power, to put it bluntly, their own people, i.e., those who were delegated by the parties and received a greater vote of confidence in elections. The status of parties, as autonomous intermediaries, is possible when they are separated from society and the state by what K. von Beyme calls "the minimal distance." ${ }^{11}$ The above-mentioned "Sartori distinction" safeguards democratic regimes from "the steam bath of popular feelings". ${ }^{12}$ If nations engaged in active and in such cases also emotional political activity, no one knows what

\footnotetext{
${ }^{9}$ Ramonaite A. Ar demokratija yra vertybe, arba kodèl lietuviams reikia stipraus lyderio? Book: Neatrasta galia. Lietuvos pilietinés visuomenès žemelapis, 2006, p.243-261.

${ }^{10}$ Sartori G. Lyginamoji konstituciné inžinerija. Kaunas: Poligrafija ir informatika, 2001.

${ }^{11}$ Beyme K. von. Parteien im Prozess der demokratischen Konsolidierung. In.: Merkel W., Sandschneider E. (Hrsg.) Systemwechsel 3: Parteien in Transformation Prozess. Opladen: Leske+Budrich, 1997, S. 23-56.

${ }^{12}$ Doubting G Sartori's distinction:"meritocracy or ignorance" because it is similar to the definition of politics without politicians, we can agree with R. Dahrendorf who pointed out post-communist democratic illusions: "Democracy, in the sense of asking people to decide, will not fill this vacuum. "We the people" can rise against the abhorrent regime of exploitation and suppression, but "we the people" cannot govern. The democratic illusion that there is such a thing as government by the people has always been an invitation to usurpers and new monopolies." (Dahrendorf R. Reflections on the Revolution in Europe. New York, Times Book/ Random House, 1990, p. 12).
} 
would remain from the current parties and political regimes. It is obvious that in democratic elections it is possible to become, for example, a member of the Lithuanian Parliament having obtained 6 percent ballot of eligible voters in the constituency only in case society does not participate. Certainly, this is not the democracy of a "thriving diversity".

Trying to avoid democratic primitivism, we will analyze parties in the narrow sense as a collection of party elite, party functionaries. Identifying power ambitions and political responsibility with all party members would not be an effective research instrument because the participation of ordinary party members in shaping party political doctrines and executing practical policy is very limited. Political doctrines of parties - a particular vision of the social world - are presented by party elites and practical policy is also executed by them. The role and responsibility of party elites are decisive for political democracy. Ch. Tilly highlights an important moment of the responsibility of party elites by pointing out that democratization is a more massive, more gradual and slower process than de-democratization, whereas de-democratization is not the consequence of society disillusionment, most often it is the result of the activity of political elites. ${ }^{13}$

The research of parties in the narrow sense is all the more reasonable because Lithuanian parties do not boast internal democracy. G. Žvaliauskas has determined that in 2007, the regulation of the internal life was democratic only in the LSDP and the Homeland Union. ${ }^{14}$ The low number of party members ${ }^{15}$ testifies to a narrow circle of persons delegating appointees for power. The relationship between a meager party membership and closed party character ${ }^{16}$ is manifested in a still narrower circle of political decision makers. Such parties are similar to M. Duverger's "cadre parties".

The fact that parties in Lithuania have established a weakly governing democracy is not the whole problem. It is important whether Lithuania is aware of the necessity to strengthen parties as the manifestation of civil society, whether weak parties are left to their own means to cope with this necessity or whether

\footnotetext{
${ }^{13}$ Tilly Ch. 2007.

${ }^{14}$ Žvaliauskas G. Ar partijos Lietuvoje demokratiškos? Kaunas: Technologija, 2007.

${ }^{15}$ A relatively small 3 per cent membership of parties is not an exceptional feature of Lithuania. The exception lies in the fact that the average size of a party does not even amount to 2 thousand members. If it were possible to estimate the number of "dead souls" in the parties, the actual membership figures in most parties would become despicably low.

${ }^{16}$ It turns out that in Lithuania, 11 percent of people would like to join parties; in case of young people - up to 20 per cent; however, 86 percent claim that they have not been delivered an invitation and have not been encouraged to engage in party activity. (Ramonaite A. Kodèl žmonès nestoja ị partijas? Lietuvos gyventojų požiūrio ì partinę narystę analizè. Politologija, 2010, Nr. 2, p. 26).
} 
attempts are made to renounce party "services" ${ }^{17}$ Ideas about the not too distant demise of parties are "rather exaggerated"; therefore, we will have to live with the criticized parties, the question being - with what parties? It is preferable to live with those capable of organizing effective political governing.

\section{Fights of Political Parties for Power and the Issue of Political Governing}

The attention of parties for political power is the norm of their activity. The norm is not violated if parties, having come to power, govern effectively. But there are numerous cases when the fight for power is hypertrophied, power is sought for the sole purpose of possessing it, but not for governing effectively. Such ambitions of those in power do not serve the solution of public problems and stimulate distrust. Effective political governing under conditions of uninterrupted party competition is feasible if there are formal and informal institutions (rules): a) predetermining the governing of competent politicians; b) supporting political elites, seeking power for the welfare of society; c) regulating conditions of party participation in the government; d) precluding the undermining of governments for assets or honor; e) guaranteeing a working opposition.

Lithuania factually exercises discontent with living conditions, concern about their deterioration and, thus, reversibility. But actually it is just a minimal feature of any area of governing that eliminates reversibility processes. We have both structural and functional problems of political governing. ${ }^{18}$ The greatest concern is that Lithuania, according to the world's economic development indicators, being down to a place somewhere in the fourth dozen (between 37 and 48), is encountering danger of slipping even further from this position. Lithuania is surpassed by separate "third world" countries. Without increasing the tempo of development, Lithuania might find itself in the "third world". But Lithuania should not be called a country "lodged in the history"; it is a catching-up country, possessing internal development resources, for the activation of which external support is necessary. Thus, we are talking not about backwardness, but about perspectives of catching up with high-development countries. Catching up requires a rapid development,

\footnotetext{
${ }^{17}$ An rgumentative discussion of Lithuanian politologists is presented in the study Partines demokratijos pabaiga. Politinis dalyvavimas ir ideologija. Compiled by A. Ramonaite. Vilnius: Versus aureus, 2009.

${ }^{18}$ Lukošaitis A. Demokratija ir politinès (valdymo) sistemos funkcionavimas Lietuvoje. Book: Konstituciniai valdžiu sandaros principai. International conference materials. Vilnius: „Valstybè žinios“, 2008, p. 111-126; Laurenas V. Lietuvos politinès valdysenos problema. Book: Naujo politinio veikimo formos Lietuvoje. Compiled by L. Bielinis. Vilnius: Vilnius University Publishing House, 2010, p. 9-35.
} 
particularly purposeful will efforts for bringing together society and the state. Who is bringing Lithuania together at present? By no means the parties. But then, what is the role of parties? Parties select those in power and submit them for approval in competitive elections. It is this "submission" and "approval" that are a particularly significant part of the democratic political process.

The Lithuanian party system has not yet developed into a formation which in strong democracies is called political stability and is associated with effective governing. Each new national election stimulates not only the establishment of new parties, but grants them levers of state power. This testifies that the consolidation of the governing class has not been finished yet. In 2004, A. Krupavičius and A. Lukošaitis stated that 6 parties (the Lithuanian Democratic Labor Party, the Homeland Union (Lithuanian Conservatives), the Lithuanian Christian Democratic Party, and the New Union (Social Liberals), the Lithuanian Liberal Union, the Lithuanian Center Union) could be treated as parties capable of participating and shaping government policy. ${ }^{19}$ By 2011 , a part of these parties had stopped existing, a still larger part had changed, whereas the line of effective (relevant) parties were supplemented by the new parties: the Party of Law and Order, the Labor Party, the National Revival Party. The two largest and decisive parties, the LSDP and the Homeland Union also evolved structurally and ideologically. The era of new parties and the consolidation of the governing class are still continuing.

The fragmentation of the political system in Lithuania is not critical. Partology authorities point out that all parties should not be taken for granted and counted. Party fragmentation of G. Sartori's "limited pluralism" or the decreasing number of parties through the system of elections in Lithuania could be discussed in favor of the likely greater political competitiveness due to a smaller number of parties. The mixed national elections system in Lithuania, having a more distinct proportional representation component, though certainly not ideal (such are non- existent), partly copes, if we follow G. Sartori's researches ${ }^{20}$ with major shortcomings of the majoritarian and proportional election systems. Those determined to reform the election system would have to decide whether to accept fewer parliamentary parties and more radical non-parliamentary parties or more parliamentary parties and fewer radical non-parliamentary parties.

It is important to remember the conditions of successful democratic governing defined by J. Schumpeter: politicians should be not only sufficiently qualified but also morally strong people; the area of political decisions should not

\footnotetext{
${ }^{19}$ Krupavičius A., Lukošaitis A. (Sud.) Lietuvos politine sistema: sandara ir raida. Kaunas: Poligrafija ir informatika, 2004, p. 308.

${ }^{20}$ Sartori G. 2001.
} 
be too broad; democratic power should be based on professional bureaucracy, having prestige, traditions, a strong sense of responsibility and an equally strong esprit de corps; strong democratic self-control is mandatory, i.e. adherence to laws, resistance to proposals by demagogues and fanatics, resistance to the temptation to overthrow the government on each suitable occasion; and, finally, respect of electors for the elected politicians. ${ }^{21}$

Without reiterating that these conditions in Lithuania are problematic, let us note that the essential interference of political governing is the concentration of parties on the part of policy called politics. It is the part in which policy is narrowed to programs-related statements and the competition for electoral votes. The elementary scheme of the political process is arranged from a two-phase link: fight for the mandate to govern (politics) and employment of the mandate to govern (policy). This link in the activity of parties is not spontaneous. In Lithuania, we observe a non-proportionately high concentration of parties on the goals of fighting for political power. For the sake of the party, the authorities tend to ingratiate themselves with electors by any means, but, having been given the mandate, ignore their will. Party activity should not limit itself to fighting for the mandate to govern, it is no less important, and for society actually most important, how the governing power employs the mandate in solving public problems.

The "clinging" of Lithuanian parties to power is confirmed by facts. The first fact is that those in power are chosen exceptionally through party channels (the indistinct exception being the institution of the President of the Republic of Lithuania), and parties have monopolized the selection of the willing to govern by allowing only those candidates that have been nominated by them, in certain cases not even party members, to participate in elections. The second fact is that party leaders that have lost elections remain in the leading positions within parties. In Lithuania there is no tradition, characteristic of strong democracies, for party leaders that have lost the elections to resign. The third fact is that politicians often change parties and factions. The fourth fact is that post-election conjuncture coalitions are formed when neither election results nor differences in election programs are taken into consideration. For the sake of the party those in power have created a situation of "ideological incognizance". E. Butkevičiene, E. Vaidelyte and G. Žvaliauskas did not find a single instance when a party, having completed negotiations for joining a coalition, had refused to participate in the Government under formation because otherwise it would have been necessary for the party to

\footnotetext{
${ }^{21}$ Schumpeter J. A. Kapitalizmas, socializmas ir demokratija. Vilnius: Mintis, 1998, p. 320-326. New interpretations of the democratic political governing are presented in: Dean M. Governing Societes: Political perspectives on domestic and international rule. London: Open University Press, 2007.
} 
betray its values. ${ }^{22}$ The fifth fact is the condemnation and elimination of the socalled "statesmen" from public life as "the traitors of the homeland". ${ }^{23}$ Certainly, in their activity, some politicians, civil servants and intellectuals did not choose democratic pessimism and populist submissiveness, did not ascribe to society innate political sense and aspired to the status of technocracy, ignored parties and their hierarchies. The rise of "statesmen" was a reaction to the efforts of party elites to preclude the formation of professional career bureaucracy which would inevitably become a power partner. The party establishment could not stand this.

The formation of conjuncture coalitions of the governing power has become the newest form of fighting for power. This phenomenon has particularly spread since the municipality elections in 2011. The history of disregard for the results of national elections was begun by President V. Adamkus in the year $2000 .{ }^{24}$ The principal plan of the "new policy" to decrease the political left-right confrontation ignored the results of the elections to the Seimas. In 2004, while forming the Seimas governing body and the Government, election results were not taken into consideration either; discredited persons laid claim and were appointed to minister positions. ${ }^{25}$

The mess of conjuncture coalitions might have no direct influence on municipality governing capability; however, it has negative consequences for the party identity of electors and trust in parties. Besides, the electors were not only disorientated, they also felt deceived. In separate cases, parties, having received the greatest number of ballots, do not become the governing power, polarized left and right parties become coalitional as successfully as much more value-related political forces. There are instances when representatives of a party participate in the activity of both the position and the opposition. Such deals of party authorities are incomprehensible not only to the electors but also to ordinary party members. Conjuncture coalitions in municipalities can be explained by the dominance of personal interests. Yet conjuncture coalitions on the national level mean nondemocracy and can grow into de-democratization because they are an internal

\footnotetext{
${ }^{22}$ Butkevičiene E., Vaidelyte E., Žvaliauskas G. Ideologija ir partinè veikla: Lietuvos partijų lyderiu požiūris. Politologija, 2009, Nr. 2, p. 33-58.

${ }^{23}$ Jokubaitis A., Lopata R. Valstybininkai: pretenzija ị sąvokos analizę. Politologija, 2009, Nr. 4, p. 57-80. I cannot agree with the authors that the term "statesman" should be associated with politics, but not with policy doctrine. The term statesman, apart from indicating exceptional professional and ethical qualities, defines not so much fighting for power but competences to resolve public problems, capabilities to coordinate interests of the state and society. Statesmen should be identified with the strategic elite.

${ }^{24} \mathrm{Ka}$ auskienè V. Lietuvos Respublikos Vyriausybès. Ju kaita ir veiklos bruožai. 1990-2007. Vilnius: Gairés, 2007, p. 484.

${ }^{25}$ Kašauskienè V. Lietuvos Respublikos Vyriausybès. Ju kaita ir veiklos bruožai. 1990-2007. Vilnius: Gaires, 2007, p. 484.
} 
agreement of the governing class, division of power while ignoring the electors. It should additionally be pointed out that conjuncture coalitional policy precludes the formation of equal value opposition.

Why are such facts possible? Perhaps due to the fact that parties have canonized themselves and their fights for power: "parties are power" and "power is parties". In this case, parties do not have to seek political power by any means, power already "belongs" to parties. Recruits of those in power are limited to party-parliamentary elites and their selection from other elites is actually null and void. Thus, no attention is paid to the fact that society has also other powers; the most powerful from them are the economic and cultural powers. Or perhaps the above-mentioned facts are possible because it is complicated to draw the difference between what $G$. Navaitis, a psychologist, calls an adequate and compensational striving for power. ${ }^{26}$ Adequate power ambitions are socio-centrist, power is sought for the welfare of society. Compensational power ambitions are ego-centrist, power becomes an instrument for satisfying personal needs. Further: in case of the compensational power ambition, internal party democracy is restricted, party authorities become particularly closed and even non-professionals become the governing power. This has a direct negative impact on the development of the country.

Lack of development determines the disappointment of society. Disappointed expectations are the greatest danger of internal security. It is necessary to add that, in catching-up societies, expectations are unreasonable; therefore, such societies get disappointed particularly fast. In the long run, the disappointment in unreasonable expectations develops into the conviction that it is the governing power that has caused the disappointment. What parties should genuinely be punished for by the electors is their inability to develop political leaders that could consolidate the disappointed society and amass it for the development; at present, party elites rather increase this disappointment by naming any changes development.

The governing power also loses because they underestimate the necessity to consult with society where more and more information keeps circulating and ever more knowledge is generated. Society, separate groups, having certain economic and educational potential, are capable of formulating their interests and are aware of their political context. Research is necessary in order to determine the reasons for such attitude of the governing power: whether it is the underestimation of society capabilities or the outcome of the governing class "kitchen" or simply arrogance of the "national representatives"? V. Nekro is claims that even when society is better

\footnotetext{
${ }^{26}$ Navaitis G. Politiku psichologija. Vilnius: Publishing House of the Union of Lithuanian Writers, 2011, p. $80-93$.
} 
informed about public activities, populist parties, seeking to get more votes, will continue to use better information in a distorted way. ${ }^{27}$ We should not discard the idea that party elites, whose interests in one way or another are associated with the success of parties and with the specific benefit of the "nation's representative" to freely formulate a policy, are trying to coordinate their mandates with their personal interests. According to P. Bourdieu, it is impossible to deny that in such a case the interests of those having the mandate and those having given the mandate to the former simply coincide. ${ }^{28}$

Being proponents of the responsibility of political elites for democratic governing, we have to pay attention to the results of scientific research on this topic in Lithuania. M. Degutis, having stated a passive reaction of a great part of Lithuania's population to a possible threat for the democratic state system, believed that the return of an autocratic regime was scarcely possible, first of all due to the standpoint of the political elite and foreign policy context; Lithuania's political elite is much more distinctly orientated towards a democratic state system than the majority of Lithuania's population. ${ }^{29}$ In later research the conclusion surfaces that such an attitude to Lithuanian political elites is too optimistic and a passive political culture, dominant in society, poses the risk of the possibility of authoritarianism and electing non-democratic politicians. ${ }^{30}$ In this discussion we can only add that political elites are genuinely more loyal to democratic governing, not necessarily as the most effective one, but by all means as the safest in terms of their status in society.

The economic, social and political situation in Lithuania is developing as if it were necessary to find room in the line of catching-up countries. Having read D.C. North, you begin to contemplate whether it is still possible to change your own "historical path"?31 Lithuania is not a hopelessly lagging-behind country; however, we should be concerned that we are not determined to effect a development breakthrough, and neither are our political parties. The latter perspective is getting away solely due to the fact that the outcome of twenty years of weak

\footnotetext{
${ }^{27}$ Nakrošis V. Strateginis valdymas Lietuvoje: ar turime rezultatu vyriausybę? Vilnius: Vilnius University Publishing House, 2008.

${ }^{28}$ Bourdieu P. Sociologija politiki. Moskva: Socio-Logos, 1993, p.187.

${ }^{29}$ Degutis M. 2002, p. 63-65. It is not the democracy of the dissatisfied, but a motive of citizens loyal to democracy. There are those believing that such citizens are supporters of reforms and agents of democratization. (Klingemann H.-D. Unterstützung für Demokratie: Eine Globale Analyse für die 1990er Jahre. In.: Lauth H.-J., Pickel G., Welzel Ch. (Hrsg.) Demokratiemessung. Konzepte und Befunde im internationalen Vergleich. Wiesbaden: Westdeutscher Verlag, 2000, S. 267-297.

${ }^{30}$ Ramonaite A. Gerove ir parama demokratijai Lietuvoje. Politologija, 2005, Nr. 2, p. 69-90; Lietuvos tauta: bükle ir raidos perspektyvos, 2007, p. 84.

${ }^{31}$ North D. C. Institucijos, ju kaita ir ekonomikos veikmé. Vilnius: Eugrimas, 2003.
} 
democracy is poor capitalism, i.e. what L. Donskis has called "social rage"32 and political elites - "perpetual policy testers". ${ }^{33}$ It is relevant to ask whether poor capitalism, social rage and perpetual policy testers are not becoming a permanent state of our society.

\section{Cases of Lack of Political Responsibility of Parties}

We attempt to define atypical political responsibility through the analysis of the nature of differentiation between predictable and unpredictable outcomes of political governing. This approach is characteristic of a sequential change in the emphases of value-related and functional traditional political responsibility, whereas the ability to govern is qualified as a component of political responsibility which is more than equal to moral governing. The traditional sequence of the emphases of political responsibility is represented by what has become a style of Lithuanian politics when the resignation of politicians who have offended against ethical standards of society is demanded; however, responsibility is hardly ever required from moral, yet ineffectively governing politicians. Political responsibility is responsibility for exercising state power (through influence or coercion) in orienting the development of the country in the politically agreed direction. The basis of political responsibility is the ability to govern, fulfilling promises, achieving set goals, and - in democracies - achieving public goals that have also been discussed with society. Political responsibility also implies value-related self-control, avoiding lies, formulating public problems and their solutions. Consequences of political responsibility/irresponsibility are overall, to a greater or lesser extent decisive for all members of society.

It is hard to determine political responsibility by rationality characteristics. Predictability of political results is a more complicated task than predictability of the activity of individual organizations or firms. In politics, it is impossible to apply the economic principle of rational profit maximization. Political choices are based on the principle of public utility which is not identical to profit maximization. The relationship between the extent and implementation time of programs proposed by politicians is not (and cannot be) proportional. Democracies do not make an exception. Trying to win elections, parties put forward as great and as rapidly implementable reforms as possible. Predictability of the outcomes of such reforms

\footnotetext{
${ }^{32}$ Donskis, L. Imagologija, manipuliacijos ir viešoji erdvè postmodernioje politikoje // Politologija, 2004, Nr. 1, p. 3-38.

${ }^{33}$ Valatka R. Amžini politikos bandytojai. Lietuvos rytas, 14 March 2011, p. 2.
} 
is always a problem. A policy, especially its politics phase, is often blamed for the lack of functionality and its ineffectiveness. If we related effectiveness and profit to the correlation of goals and results of the activity, we would notice that often goals and results of a policy do not coincide, whereas what is effective is not useful for all. This can be seen while facing health care, pension, education and science, finance, energy and other public issues. What is useful for some social groups is of no use for others. Parties are forced to constantly solve the task of how to move from usefulness for separate social groups to the manifestation of usefulness for the entire society. It is a natural dispersion of political responsibility. Political responsibility undergoes this dispersion through the involvement of parties in a coalition government or after a party forms a minority government. Because of this, unexpected results cannot be avoided in politics.

Below two cases are presented when Lithuanian parties ignore their responsibility - cases which do not fit in the framework of "the normative" of the inevitably unexpected results. They are political no-truth turning into a lie and the left orientation inconsistency of the LSDP.

\subsection{Relationship of No-Truth and Lies in Politics}

"The factual truth is characterized by the fact that the opposite of it is neither a mistake, nor an illusion, nor an opinion, nor truth reflecting personal righteousness; such an opposite is conscious no-truth or lie". ${ }^{34}$ Using this generalization made by $\mathrm{H}$. Arendt, we want to develop our own conception of the difference between a no-truth and a lie in politics. However, prior to that, let us consider two Lithuanian realities.

"We'll fix the Seimas - we'll make order in the state", - it seems that apart from stylistic problems, everything is correct in this statement. However, when we found out that this is part of a political advertising of the 2011 election to the Seimas in the single-mandate district of Dané, we have doubts. As simple as that - one new member will "fix" the Seimas! It is obvious that this is no-truth, but isn't it a lie?

In his assessment of the resignation of the Minister of Economy D. Kreivys and the failed interpellation against the Minister of Energy A. Sekmokas, former President V. Adamkus noted: "I do not intend to judge about the extent of dishonesty, fallacy $\langle\ldots\rangle$, but I see that truth is the least concern of politicians" ${ }^{35}$

It is often claimed that to gain power, politicians have to lie. It would be

\footnotetext{
${ }^{34}$ Arend H. Tarp praeities ir ateities. Vilnius: Aidai, 1995, p. 275.

${ }^{35}$ Bartusevičius A. Būtinas moralinis lūžis. Lietuvos rytas, 14 March 2011, p. 2.
} 
more sensible to say that political rhetoric is dominated not by lies but by naturally not telling the truth. Without reiterating frequent statements about rare compatibility of politics and truth, let us note how little attention is devoted to the culture of no-truth inherent to politics and which is not foreign to society either. Of course, V. Kavolis would have reminded us of the value-related nature of culture, that culture sets moral requirements and does not imply any generality of behavior; there are generalities of behavior - poverty, violence, etc. - that are not appreciated, protected, wanted by the members of such "cultures" themselves. ${ }^{36}$ We can justify ourselves only by the fact that culture here is related not to lie, but to unawareness of truth, fallacy.

There is no need to be one-sided critics of parties and each and every party leader. P. Bourdieu observed that the official truth of an official person, the cult of public service and loyalty to society welfare will not withstand distrustful criticism which everywhere detects corruption, careerism, clientelism or, in the best case, a private interest in serving the general welfare ${ }^{37}$ However, there is emerging a tendency that parties and their leaders often lie to society or too often consciously "err".

P. Bourdieu's moderate relativistic conception of truth in politics should be discussed in our research. ${ }^{38}$ Having no possibility to present it in detail, let us emphasize its underlying motive; to society, truth is what social groups think about themselves and try to universalize, while politicians, seeking to become mouthpieces of the interests of the groups, have no right to ignore the beliefs idealized by these groups; the groups acknowledge only those politicians who publicly demonstrate their own acknowledgement of the beliefs of these groups. Politicians earn profit, acknowledging social ideals, intending and promising to implement them. We have to add here that politicians act in the environment where "truths" of groups are not identical, whereas society is a totality of social groups that "have correctly perceived their interests". With reference to $\mathrm{H}$. Arendt, who states that truth is what we cannot change, ${ }^{39}$ lie will be the avoidance of truth independent of social groups.

The difference between no-truth and lie is the difference between an error or "a noble lie" and conscious deception, not telling the truth. ${ }^{40}$ The nature of no-truth in politics may be called natural. Political problems are getting more

\footnotetext{
${ }^{36}$ Kavolis V. Kultūros dirbtuve. Vilnius: Baltos lankos, 1996.

${ }^{37}$ Bourdieu P.1993, p. 329.

${ }^{38}$ Bourdieu P.1993, p. 323-327.

${ }^{39}$ Arendt H. 1995, p. 291.

${ }^{40}$ In the Lithuanian tradition of research on lie, this differentiation is defined more carefully: "The boundary between a lie as conscious deception and an error as unconscious deception in some cases can be very vague" (Maldeikis P. Melas kaip pedagoginé problema. Kaunas: "Šviesa" Press, 1938, p. 8).
} 
complex and global; it is more complicated to trace their causes and harder to forecast them, and it is still harder to solve them. No-truth in politics is related not only to the capabilities of politicians and experts to formulate and solve public problems, but also to the expectations of society. A flaw in democracies is the fact that politicians, in their mutual competition, making promises escalate unrealistic expectations of society as to what the government can deliver. And hence, "no one, trying to cool down citizens' expectations to a realistic level can gain political points" ${ }^{41}$ Even professionalization of politics does not counterbalance no-truth. Lying in politics has different origins: a conscious not-telling of the truth is determined by fear or self-interest as well as unprofessionalism. Unprofessionalism is not justification of unawareness of truth. A lie can often be organized in politics; political discipline also implies discipline in lying. However, if a party possesses internal democracy, it foresees the possibility to avoid factions and, at the same time, "disciplined lie".

No-truth in politics has three forms: 1) no-truth as a promise (an ontological form of no-truth in politics); 2) no-truth as a secret (a consequence of state secrets); 3) no-truth as unprofessionalism (a consequence of demagogy, naivety or lack of expert knowledge).

Known causes of an excessive extent of no-truth in Lithuanian politics are: 1) four-fold and rapid post-communist transformation; 2) unreasonable expectations when society expects from politics and itself more than is really possible; 3) natural unprofessionalism of politicians at the beginning of the transformation and lack of professionalism during subsequent periods. A certain increase of the extent of no-truth at the beginning of the post-communist change was justifiable. It was determined not by an exceptional inclination of Lithuanian politicians not to consciously tell the truth. A new social structure was developing in the environment of chaos; it was more evident what kind of potential was being lost with the old social layers withering away, but there was no clue what potential of the development the new social layers were going to have. The new political elites did not know their potential either. With hope and enthusiasm the Lithuanian society took all promises to improve the living conditions as well as references to the enemies interfering with a better life. Failure to fulfill these promises even led to political success; it was the enemies that were precluding the implementation of noble ambitions. Thus, politicians were telling the things that society wanted to hear and expected. But truth is not always what society thinks; besides, it also changes its opinion. Meanwhile, those in power have not changed "the tape". Why now the statements about "Lithuania making progress" are considered deception

${ }^{41}$ Dunleavy P., O‘Leary B. Valstybès teorijos: liberalios demokratijos politika. Vilnius: Eugrimas,1999, p. 127. 
by society? Because society is in a state of frustration. Because reforms that gave hope bring unpredictable and unexpected outcomes. Today, twenty years after the restoration of the independence of the state, this can no longer be justified; this is a flaw of those in power. Eventually, it is becoming obvious that promises turn into conscious deception in seeking power; parties and their leaders promise changes, being aware of their unimplementability.

In Lithuania, the extent of telling no-truth is so great that experts find it difficult to distinguish when politicians tell no-truth and when they lie. Different assessments should be used concerning the ratio of no-truth to lie when selling "Mažeikių nafta" or disclosing the account of the Belorus opposition organization, ratifying the collapsed Constitution of the EU or forming conjuncture coalitions, speaking about the construction of the new nuclear power plant or avoidability of the economic crisis. The fact that the extent of no-truth in Lithuanian politics exceeds natural boundaries is indicative of what M. Edelman identified as "ambivalent attitudes of society". ${ }^{42}$ Such attitudes indicate skepticism and distrust towards promises and work, while political support for both parties and state institutions is getting more and more accidental and unpredictable. Massive flows of no-truth are identified with conscious not telling truth. And then, absolutely regardless of the explanations of what in Lithuanian politics is no-truth and what is lie, what arises from self-interest of professional politicians and what from the naivety of unprofessional politicians, distrust of society in governing power amounts to delegitimation.

\subsection{Inconsistency of Political Leftness of the LSDP}

One of the reasons why the activity of parties in Lithuania has not yielded results was the Lithuanian Democratic Labor Party and, later, the doctrinal posture and practical policy of the LSDP. The LSDP made too pronounced a shift towards the political center, causing a problem of a political left-wing systemic party. Recently, attempts have been made to prove that the left-wing political power is not necessary either to capitalism or democracy; there is an ongoing discussion on the sense of the distinction between the political left- and right-wings. It is worth recalling that attempts are made not to see the differentiation between left and right when one of the wings of the political spectrum finds itself in crisis. ${ }^{43}$ At present, the left wing is in crisis. However, capitalism ceaselessly creates the necessity of

\footnotetext{
${ }^{42}$ Edelman M. Politinio spektaklio konstravimas. Vilnius: Eugrimas, 2002, p. 66.

${ }^{43}$ Bobbio N. Kairè ir dešine: politine skirtis. Vilnius: UAB „Apostrofa“, 2004, p. 69-75.
} 
new left-wing parties; it can't help actualizing the values of equality. Still greater need for left-wing parties is created by poor capitalism. It is worthwhile seeing what happens when parties that call themselves left-wing parties are incapable of communicating with people who cherish left-wing values.

In research on Lithuanian parties, the differentiation between left and right is one of the most oft analyzed topics. ${ }^{44}$ There is a prevalent question: why do Lithuanian parties, let us generalize, seek ideological neutrality? Also, there is a focus on the necessity for parties to establish a more distinct identity within the left-right spectrum. The absence of the ideological identity of parties is called a systemic problem. ${ }^{45}$ Lithuanian politologists notice a relationship between the increasing number of people who do not relate themselves to any party and the decreasing turnout in elections. Yet, it has not been defined if in this case there is lack of clear ideological posture of the parties or there are doubts about their political competence. Meanwhile, de-ideologization is called pragmatism by politicians.

"Ideological neutrality" manifests itself within all party systems. It is determined, first by the diversity of the complex of needs and interests of modern people - diversity that "does not fit" into any one of the systems of ideological views; second, substitution of long-term and universal political programs for separate ones, orientated towards local problems, and therefore often changing programs; also, substitution of ideologies with the results of public opinion polls. Although Lithuanian parties avoid ideological identification (the Homeland Union even removed the term conservatives from its name), facts testify that in 1994 approximately 80 per cent and in 1999 about 60 percent of the Lithuanian population indicated their identity on the left-right scale. In countries of the Western and Northern Europe, such population makes up more than 80 percent. ${ }^{46}$ These figures alone suffice to state that the ideological differentiation between political left and right is not losing its functionality.

The inconsistency of the LSDP left-wing political orientation has two, yet weighty, justifications that are not dependent even on it: 1) The Lithuanian party system is not structured, therefore all parties are still construing their identity. 2)

\footnotetext{
${ }^{44}$ Novagrockiene, J. Lietuvos partinès sistemos raida. Book: Seimo rinkimai '96. Trečiasis “atmetimas". Compiled by A. Krupavičius. Vilnius: Tverme, 1998 p. 298-324; Jurkynas M. Politinio konflikto kaita ir takoskyros. Book: Lietuva po Seimo rinkimu 2000. Compiled by A. Jankauskas. Vilnius, Kaunas: Naujasis lankas, 2001, p. 23-33; Novagrockiené, J. Seimo rinkimai 2000: partinés sistemos evoliucija ar transformacija? Book: Lietuva po Seimo rinkimu 2000, p. 51-61; Ramonaite A. The End of the Left-Right Discourse in Lithuania? In Lithuanian Political Science Yearbook 2002. Vilnius: Vilnius University Press, 2003. P.22-37; Krupavičius A. Partiju programos ir vertybès $2004 \mathrm{~m}$. Seimo rinkimuose. Book: Lietuva po Seimo rinkimu 2004. 2005, p. 11-34; Ramonaite A. Posovietinés Lietuvos politine anatomija. Vilnius: Versus aureus, 2007.

${ }^{45}$ Butkevičienė E., Vaidelytė E., Žvaliauskas G. 2009, p. 33-58.

${ }^{46}$ Data source: Novagrockienè J. 2001, p. 57; Ramonaite A. 2007, p. 52-53.
} 
In 1992 - 1996, the governing LSDP had to create the foundations of an effective economic system - capitalism - and be more pro-capitalist than socialist.

G. Sartori "sees" a structured party system when voters identify themselves not with party celebrities, but with abstract images of the parties (when it is not the leader who "selects" the party, but the party "selects" the leader), whereas organized mass parties oust and, on a large scale, change celebrity parties. ${ }^{47}$ There are two organized mass parties in Lithuania - the LSDP and the Homeland Union, but they do not even try to "oust" celebrity parties from the political arena. The elimination of the two-stage voting in 2000 was beneficial for the latter parties, while the LSDP and the Homeland Union, having trusted the new allies, have already gone through running unstable coalition governments. Of course, electors cannot identify themselves with party images if such do not exist, but there are just famous (well-known) personalities. Two decades ago, parties, with the exception of the LSDP and the Homeland Union (Lithuanian Conservatives), were forming at the level of parliamentary groups, and those that have formed during the last decade can be characterized by exceptional personification. A low living standard offers the perspective of clientelism to a personified activity. "Celebrity" parties are not a mere whim of famous people who wish to govern; society, which is not satisfied with the governing parties, supports new non-systemic parties.

In research on Lithuanian parties, the problem of the structure of political left is not being discussed. ${ }^{48}$ We can use G. Sartori's definitions of systemic and anti-systemic parties. ${ }^{49}$ In order to simplify G. Sartori's anti-systemic differentiation, a non-systemic party concept is suggested. Systemic parties are potential parties which, upon receiving an electoral mandate, are capable of forming or considerably influencing the formation of the government as well as governing. We understand non-systemism not as a modification of anti-systemism (extreme criticism of the political system or even a demand for a change in the political state system), but as that of systemism. It is important to emphasize it since non-systemism is often identified with anti-systemism. Non-systemic parties differ from systemic ones in their incapability to form a government, yet they are capable of dampening the outbursts of "risky classes" and anti-systemic (extremist) parties. Left-wing non-systemic parties are an emancipation reaction, often populist, to the non-decreasing social inequality and social injustice. Following the same social logic as systemic parties (otherwise they would not be legal participants of the political process), non-systemic parties are "a lightning rod" protecting the political regime from the discharge of extreme

\footnotetext{
${ }^{47}$ Sartori G. 2001, p. 53-54.

${ }^{48}$ Laurenas V. Pokomunistine politinė „kairioji“ ir jos struktūra. Tiltai, Appendix 13, 2003, p. 256-268.

${ }^{49}$ Sartori G. 2001, p. 50-52, 79-80.
} 
social tensions and maintaining the social balance. Non-systemic parties also look for recruits in anti-systemic social movements, "annexing" them, i.e., granting them the citizenship of the existing political system. Compensation offered to non-systemic parties is a priority partner of the governing coalition.

The problem lies in the fact that the potential of the non-systemic parties - the People's Party, the Labor Party and the Party of Order and Justice - can amount to the potential of the systemic LSDP. A social structure is being formed where "risky classes" or social groups, markedly losing in the division of assets, information and power, are becoming more massive. There are at least three categorical reasons to expand on the problem of "risky classes": first, Lithuania has become a society of constant unemployment; second, economic recovery waves can no longer in any way change the situation of "risky classes" throughout the world; third, internal security fails when "risky classes", feeling disappointed and helpless, resort to unpredictable actions only because it is better to do anything because only this makes you feel a member of society and not a standby observer. The problem is simplified when the increasingly numerous "risky classes" of the information society are considered to be unaware of political contexts, keeping silent and making mistakes in elections. ${ }^{50}$ "Risky classes" are made silent by "speaking" or majority classes. ${ }^{51} \mathrm{R}$. Dahrendorf does not ask now, as twenty-five years ago, why these classes "don't fly into rage and break furniture in the house that has been built by a majority class for itself?" ${ }_{2}$ "Risky classes" are raging already, they are looking for parties that have no "centristic" illusions and, having not found them, move towards anti-systemic radicals and take to the streets. ${ }^{53}$

Left-wing orientation of the LSDP, one of the strongest systemic parties, has dwindled to such an extent that it cannot counterbalance social bifurcation that is already under way. Using A. Krupavičius' conclusion that the competitive axis of Lithuanian parties on the economic left-right scale shifted from the center-right in 2000 to the center-left position in $2004^{54}$, we can observe that this shift took place without any effort of the LSDP. The LSDP crossed the boundary of the political center-left. A. Ramonaite provides data on the research carried out in 2005 on the

\footnotetext{
${ }^{50}$ Baločkaite R. Už reprezentacijos ribų: tylinčios klasès. Book: Demokratija be darbo judëjimo? Compiled by A. Bielskis. Vilnius: „Kitos knygos“, 2009, p. 140-160.

${ }^{51}$ Once again it is worth to remember J. A. Schumpeter and his "other theory of democracy": society is separated from the shaping of "the national will" by politicians; democracy only implies that people have the possibility to acknowledge or not to acknowledge those who, having won over electoral votes in free competition, are going to govern them; simple majority decisions distort rather than express the will of society (Schumpeter J. A., 1988, p. 297-313).

${ }^{52}$ Dahrendorf D. Socialinis konfliktas. Vilnius: Pradai, 1996, p. 239.

${ }^{53} \mathrm{M}$. Laurinkus is surprised why " $<\ldots . .>$ politologists look down on contemporary marginal political formations and estimate them only through the prism of the Seimas 5 per cent barrier" (Laurinkus M. Be kaukès. Lietuvos rytas, 27 August 2011, p. 4).

${ }^{54}$ Krupavičius A. 2005, p. 32.
} 
opinion of the Lithuanian people regarding the distribution of parties on the political left-right scale (when 1 means extreme leftism, while 9 means extreme rightism): the Labor Party -3.28 , the Peasants and New Democratic Party Union - 4.16, the Party of Order and Justice (LDP) - 4.18, the New Union - 4.31, the LSDP 5.03, the Liberal and Center Union - 5.31, the Homeland Union - 7.03, whereas 35 per cent of New Union electors, 27 per cent of Peasants and New Democratic Party Union electors, 24 per cent of Labor Party electors, 14 per cent of Order and Justice Party (LDP) electors would have voted for the LSDP as the second party. ${ }^{55}$ A conclusion could be drawn that, having lingered in the political center, the LSDP does not consistently shape the political will of left orientation electors.

The reasons for the LSDP "centrism" are the following: 1) it is unpopular in post-communist countries to identify oneself with the political left; 2) the inevitable post-communist pro-capitalist orientation; 3) the erroneously assessed (overestimated) by the LSDP Lithuania's possibilities to create "a wealth state".

From 1992 to 1996, the LSDP gave priority to the values of inevitable and therefore supportable post-communist pro-capitalism, whereas greater social equality, solidarity and other leftist values were made subordinate to the former ones. ${ }^{56} \mathrm{Also}$, there were hopes that the rapid development of capitalism will create a social liberal middle class. As is known, this did not happen. Eventually, attempts were made to subordinate market and equality values the other way round, yet time was gone and electors lost; left "celebrity" parties took over the majority of left electors. A historically complicated shift of the LSDP to the political center awakened populist parties, opened a political perspective for them and, in a way, legitimized them. One of them - the Labor Party - even "borrowed" a notional part of its name from the LSDP. By the way, the LSDP did not manage to stimulate rich capitalism in Lithuania. Other parties did not greatly contribute to the development of such capitalism either.

From 2001 to 2004, as a governing party, the LSDP lost the election to the European Parliament, the preliminary Presidential election and, essentially, the election to the Seimas. It happened at the time when in the post-communist development of Lithuania the most impressive results were achieved: in politics joining NATO and the EU, in economy - the fastest growing GDP in Europe. So maybe R. Dahrendorf is right in claiming that with its success social democracy is paving a "death" road for itself? ${ }^{57}$ Or maybe, on the contrary, the LSDP experienced

\footnotetext{
${ }^{55}$ Ramonaitè A. 2007, p. 59, 72-74.

${ }^{56}$ Laurenas V. Populism as an Outcome of Post-communist Democratic Primitivism and Pro-capitalism. In: Lithuanian Political Science Yearbook 2005. Vilnius: Vilnius University Press, 2006, p. 49-84.

${ }^{57}$ Dahrendorf R. 1990.
} 
failures because, emulating social democracy of the developed countries, it moved towards the political center too early? From 2001 to 2008, the LSDP, dominating in the governing coalitions, did not manage to timely change its doctrine.

With LSDP leftism remaining inconsistent, electors are turning away from the party, not recognizing real left power in it or protesting against its shift to the political center. By shifting in the political center, the LSDP is losing systemism based on left values. Individual intellectuals already highlight the necessity for alternative left politics. ${ }^{58}$ The long-stay lack of consistent left orientation radicalizes people of left orientation, encourages them to come together round the Socialist People's Front, the President's Union or any other possible, maybe even anti-systemic, political power. Lithuania is losing internal security in the part of society that actualizes left values.

\section{Conclusions}

Our attention to political parties is determined by the principle of "the vertical democracy": political democracy is a form of governing and political elites are responsible for the effectiveness of political governing as well as internal security. Internal security in democracies, with the party rain "pouring down", is not a self-evident issue. The analysis confirms that harmony between the activity of Lithuanian parties and internal security is problematic. This harmony is hindered by negative features of the parties which cannot be defined as accidental or temporary; they have already become systemic. Leaders of the parties that are irresponsible representatives, select not only politically competent governing members, do not properly perform the role of an intermediary in coordinating interests and have no support of society, are not capable of organizing effective political governing.

With the exception, to some extent, of the LSDP and the Homeland Unionithuanian Christian Democrats, inherent political power ambitions of parties in Lithuania are inadequate to the capabilities of their political governing. This is because it is not the parties who nominate competent governing members, but those striving to govern create parties allegedly "nominating" them. Such parties can only create the phenomenon of politics "in itself", i.e. to fight for power; however, having gained it, they are not able to govern effectively. Thus, a weak democracy is created. Parties' fights for power in all democracies border, in a risky

\footnotetext{
${ }^{58}$ Demokratija be darbo judejimo?, 2009.
} 
way, on internal security; however, when parties demonstrate greater competences in fighting for power than in solving public problems, internal security faces a real danger. In Lithuania, a catching-up country, fights of parties for power decrease the abilities of society to formulate a general objective and implement it.

Inadequate ambitions of political power are characteristic of irresponsible parties and party elites that do not abstain from lie when no-truth, which is natural for politics, is substituted for conscious deception. Ontologically explainable notruth in politics has its limits. Such limits occur when claims for political governing separate from truth to such an extent that they lose legitimacy based on which those in power interrelate with the understanding and involvement of the ruled ones. Distrust in the governing power is a manifestation of the division between the ambitions of power and truth. Political no-truth is not requalified into lie by society when the governing power consults with citizens and in making decisions take into considerations these consultations, in fact, profit ambitions of social groups. Responsible governing is effective political governing.

Based on research on political involvement carried out by other scientists and employing the post-democratic analytical dimension, we should stress that there is no evidencs of post-democracy in any of its meanings. There is no involvement in politics not because everyone is satisfied with democracy and expects that those in power are going to adhere to the principles of democracy without control of society. Political non-involvement is rather de-legitimation of parties and political regime in general. But this is not because the governing power does not adhere to the principles of democratic governing; on the contrary, they are more favorable to democratic governing as a governing system which is more beneficial to them than society. The actual problem is that the favor of the governing power for democracy is not identical to political competence and effective governing. So far, it is not weak parties that change, but a weak democracy that remains. A weak democracy does not satisfy society's expectations but disappoints it. In a weak democracy, it is impossible to find any more dependable link between internal security and irreversibility of political democracy. It is more evident that an uninvolved society and parties lacking internal democracy stimulate non-democratic elements (political power is sought regardless of competences to govern; division of power is based on conjuncture; truth about public matters is avoided; resolution of public conflicts is delayed; political alienation is thriving). It is not yet clear what scope of irreversibility non-democratic elements have gained, which, in view of Lithuanian perspectives, can imply that a political reform cannot be overruled. However, it is clear that irresponsible political elites are decreasing the internal reliability of Lithuanian democracy as well as the readiness of society to 
cooperate for the sake of common goals. Thus, the question - what is the possibility of internal security and irreversibility of political democracy in Lithuania - does not offer a straightforward answer.

The relationship between irresponsibility of parties and lack of internal security is not one-sided. Lithuanian society itself has lived too long with unreasonable expectations and self-deceptive illusions about "the fastest history in the world". Society that is trying to catch up encouraged parties to make unrealistic promises. However, with the phenomenon of politics "in itself" still spreading and the incompleteness of reforms becoming a massive phenomenon, society is becoming aware that the management of its public matters is in crisis. Public reaction to a weak democracy is not unambiguous. Paradoxically, a disappointed society does not reject the losing governing power. In the environment of faceless parties, it is becoming less important to society who is in power; society is concerned about the way of governing, and not even in terms of the form of governing, but in terms of the results of governing. A passive society does not undertake activities to strengthen parties as an act of the manifestation of civil society, leaving parties to their own means to cope with the tasks of their governing capabilities. This, however, does not justify parties that are unable to organize effective political governing and thus reduce internal security.

September 2011 